\title{
The Association of CYP2E1 Polymorphism and Environmental Factor in Nasopharyngeal Carcinoma Patients
}

\author{
Farhat Farhat ${ }^{1 *}$, Elvita Rahmi Daulay ${ }^{2}$, Jessy Chrestella ${ }^{3}$, Raudah Putri Syari ${ }^{4}$ \\ ${ }^{1}$ Department of Otorhinolaryngology Head and Neck Surgery, Faculty of Medicine, Universitas Sumatera Utara, Medan, \\ Indonesia; ${ }^{2}$ Department of Radiology, Faculty of Medicine, Universitas Sumatera Utara, Medan, Indonesia; ${ }^{3}$ Department of \\ Anatomic Pathology, Faculty of Medicine, Universitas Sumatera Utara, Medan, Indonesia; ${ }^{4}$ Faculty of Medicine, Universitas \\ Sumatera Utara, Medan, Indonesia
}

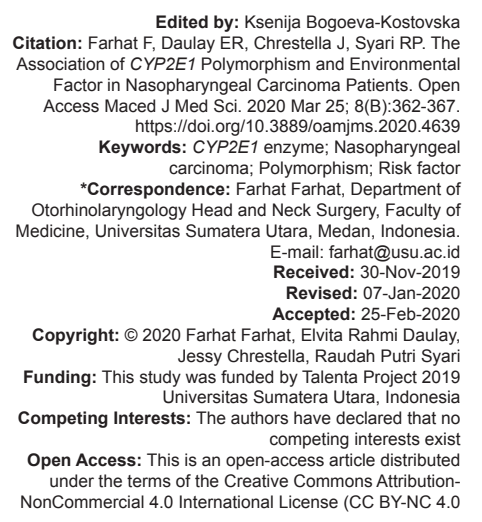

\begin{abstract}
INTRODUCTION: Polymorphism of CYP2E1 induces nasopharyngeal carcinoma (NPC) by activating procarcinogens including nitrosamine. Environmental factor such as salted fish, preserved food, tobacco, and alcohol consumption which contains nitrosamine, join with CYP2E1 polymorphism leads to an increase of susceptibility for NPC.

OBJECTIVE: The aims of this study were to identify CYP2E1 polymorphism and the association with other risk factors to NPC in NPC patients.

METHODS: This study was analytic research with the case-control design. The samples were taken based on nonprobability consecutive sampling method. The identification of CYP2E1 polymorphism was done by the PCR-RFLP method. The association of its variable to NPC was analyzed with the Chi-square test and between polymorphism of CYP2E1 with other risk factors was analyzed with stratified analysis.

RESULT: We found that there was no significant association of CYP2E1 polymorphism with NPC. However, the joint effect of CYP2E1 polymorphism with smoking was significant in NPC patients. The risk for NPC in the combination of those two was 4.0 -fold.

CONCLUSION: The study showed the capability of genetics and environment in the development of NPC. Further study can be done to find evidence of genetics and environmental influence in the prevention and treatment of NPC.
\end{abstract}

\section{Introduction}

Nasopharyngeal carcinoma (NPC) arising from nasopharynx epithelium and is developed by the relation of genetic, Epstein-Barr virus (EBV) infection, and environment [1], [2]. NPC has a unique geographic distribution which common in South China and Southeast Asia [3], [4]. There were 86.500 cases of NPC and 50.000 deaths due to NPC worldwide [5]. In Indonesia, there are about 13.000 cases of NPC per year [6]. Based on age-standardized rate, there were $8.3 / 100.000$ in males and 3.0/100.000 in females for the incidence of NPC in Indonesia based on GLOBOCAN 2012 [7]. The disease is in the fourth rank for the most common cancer in Indonesia and the most frequent for head and neck cancer [8].

Genetic, EBV infection and the influence of the environment had been known as the etiology of NPC [9]. The distinct pattern for distribution of NPC was thought as the result of genetic and environment interaction [10]. Contribution of genetics in the development of NPC includes alteration of the chromosomal regions and genes and also epigenetic alteration such as DNA methylation [11]. Genetic polymorphism was also known to be associated with NPC. Cytochrome P450 2E1 (CYP2E1) is an enzyme works in activating nitrosamine and related carcinogen metabolism. Polymorphism of this enzyme which is homozygote mutant genotype $(-/-)$ is associated with increased risk of NPC [10], [12]. This polymorphism is related to the increased enzyme activity of CYP2E1 [12].

Clear geographic distribution of NPC is related to the dietary habit of the population in the endemic area including salted fish and preserved food consumption. This diet contains nitrosamine as carcinogen. However, smoking also has a role in the development of NPC [13], [14]. Nitrosamine, besides it is contained in the food, also can be found in tobacco [15]. This carcinogen is a genotoxic carcinogen that induces DNA mutation, leading to malignancy development [16], [17]. We did the study to analyze the role of genetic, polymorphism of CYP2E1, and environment as the risk factor for NPC patients in General Hospital Haji Adam Malik Medan. There was no study about this in Medan. The result can be used as the basic data of the further studies ahead in analyzing the interaction of other genetics factors of NPC with the risk factor. Therefore, it can support that intervention of the genetic and risk factor of NPC is important in the treatment and prevention of NPC. 


\section{Materials and Methods}

\section{Patients and samples}

The study was analytic research with a case-control design. The case group was the NPC patients diagnosed based on history taking, physical examination and histopathological evaluation in the Department of Otorhinolaryngology, Head and Neck Surgery, Adam Malik General Hospital Medan. The control group was with the same frequency with the case group and does not have a history of cancer. The inclusion criteria were the NPC patients who agreed to be the participants in the study and the exclusion criteria were the NPC patients who have other malignancies. The interview was done to obtain information on the risk factors of NPC patients.

The samples of the study were the DNA extracted from $2 \mathrm{ml}$ of blood taken from the NPC patients and the controls. The identification of CYP2E1 polymorphism by PCR-RFLP was done in the Integrated Laboratory of the Faculty of Medicine of Universitas Sumatera Utara. The blood was collected in EDTA blood collection tubes and then performed DNA extraction using the Wizard Genomic DNA Purification Kit 100 Isolation $^{\circledR}$ (PROMEGA, United States of America).

\section{PCR-RFLP analysis}

DNA isolation product was used for PCR analysis. We used a method from the usage information of the $\mathrm{GoTaq}^{\circledR}$ Green Master Mix for amplification. There was $25 \mu$ total reaction volume with each sample consisted of $12.5 \mu \mathrm{l}$ of the $\mathrm{GoTaq}^{\circledR}$ Green Master Mix, $1 \mu \mathrm{l}$ of forwarding primer, $1 \mu \mathrm{l}$ of reverse primer, $2 \mu \mathrm{l}$ of DNA template, and $8.5 \mu \mathrm{l}$ nuclease-free water. We used the PCR method by Ghania et al. to identify CYP2E1 polymorphism using Rsal digestion [12]. This study used 5'-CCAGTCGAGTCTACATTGTCA-3' as the forward primer and 5'-TTCATTCTGTCTTCTAAC-TGG-3' as the reverse primer. There were 40 cycles in this PCR method with the thermal condition of $92^{\circ} \mathrm{C}$ for $1 \mathrm{~min}, 60^{\circ} \mathrm{C}$ for $1 \mathrm{~min}$, $72^{\circ} \mathrm{C}$ for $2 \mathrm{~min}$, and final elongation at $72^{\circ} \mathrm{C}$ for $5 \mathrm{~min}$. Then, it continued with the RFLP method by digestion of $5 \mu \mathrm{l}$ of samples with $0.2 \mu \mathrm{l}$ Rsal at $37^{\circ} \mathrm{C}$ overnight. We continued electrophoresis using agarose gel $2 \%$ and visualized the bands under ultraviolet transilluminator.

\section{Statistical analysis and ethics}

The data were analyzed using the Statistical Package for the Social Sciences (SPSS) 23.0 computer program. The distributions of the cases and controls were analyzed using the Chi-square test. The association of CYP2E1 polymorphism with other risk factors to NPC was analyzed using stratification analysis with the value for a risk factor that was mentioned with OR (odds ratio). The result was said to be statistically significant if the two-sided $p<0.05$. This study has been approved by the Health Research Ethical Committee, Medical Faculty of Universitas Sumatera Utara/Adam Malik General Hospital and the methods did not contradict with the Declaration of Helsinki.

\section{Results}

In the study, we found there were $21(56.8 \%)$ patients in the age group of 41-60 years old. It had the highest number than any age group. Male was dominant than the female with a comparison of 2.7:1. We found that WHO type 2, non-keratinizing squamous cell carcinoma was the most common histopathological type of NPC in the study with $23(62.2 \%)$ patients. In control, age group of 41-60 years old had a higher number with $21(56.8 \%)$ persons, and slightly different from the age group of 21 to 40 years old with $16(43.2 \%)$ persons. The data are shown in Table 1.

Table 1: Demographic distribution based on age, gender, and histopathological type

\begin{tabular}{lll}
\hline Characteristics & Case (\%) & Control (\%) \\
\hline Age (years old) & 0 & 0 \\
$<21$ & $13(35.1)$ & $16(43.2)$ \\
$21-40$ & $21(56.8)$ & $21(56.8)$ \\
$41-60$ & $3(8.1)$ & 0 \\
$>60$ & & $15(40.5)$ \\
Gender & $27(73.0)$ & $22(59.5)$ \\
$\quad$ Male & $10(27.0)$ & \\
$\quad$ Female & $5(13.5)$ & \\
Histopathological type & $23(62.2)$ & \\
WHO type I & $9(24.3)$ & \\
WHO type II & \\
WHO type III &
\end{tabular}

Table 2 shows several risk factors of NPC and its distribution in the NPC patients and non-NPC patients. We found that homozygous wild type genotype $(+/+)$ was the most common for CYP2E1 genotype with $24(64.9 \%)$ patients in case and $26(70.3 \%)$ in control. This genotype had the band which is visualized in the $50 \mathrm{bp}$ and $360 \mathrm{bp}$. The heterozygous mutant genotype $( \pm)$ resulted in the presence of band in $50 \mathrm{bp}, 360 \mathrm{bp}$, and $410 \mathrm{bp}$. We found $3(8.1 \%)$ NPC patients and $5(13.5 \%)$ persons with this type of CYP2E1 genotype. There were $10(27.0 \%)$ NPC patients and $6(16.2 \%)$ persons carrying homozygous mutant genotype $(-/-)$ in this study. This genotype resulted in the presence of band in $410 \mathrm{bp}$.

Table 2: Distribution of CYP2E1 polymorphism and other risk factors in case and control and the risk for NPC

\begin{tabular}{|c|c|c|c|c|}
\hline O risk factor & Case $(\%)$ & Control (\%) & $p$ value & OR (Cl 95\%) \\
\hline \multicolumn{5}{|c|}{ CYP2E1 genotype } \\
\hline$+/+$ & $24 / 37(64.9)$ & $26 / 37(70.3)$ & $>0.05$ & \\
\hline$+/-$ & $3 / 37(8.1)$ & $5 / 37(13.5)$ & $>0.05$ & \\
\hline$-1-$ & $10 / 37(27.0)$ & $6 / 37(16.2)$ & $>0.05$ & \\
\hline \multicolumn{5}{|l|}{ Smoking } \\
\hline+ & 23/37 (62.2) & $12 / 37(32.4)$ & $<0.05^{\star}$ & $3.423(1.315-8.909)$ \\
\hline - & $14 / 37(37.8)$ & $25 / 37(67.6)$ & & \\
\hline \multicolumn{5}{|c|}{ Drinking alcohol } \\
\hline+ & $4 / 37(10.8)$ & $2 / 37(5.4)$ & & \\
\hline - & $33 / 37$ (89.2) & $35 / 37(94.6)$ & $>0.05$ & \\
\hline \multicolumn{5}{|c|}{ Salted fish and preserved food consumption } \\
\hline+ & 28/37 (75.7) & $29 / 37(78.4)$ & & \\
\hline - & 9/37 (24.3) & $8 / 37(21.6)$ & $>0.05$ & \\
\hline
\end{tabular}


Based on the smoking status, in NPC patients, there was a higher number of smokers than non-smokers with $23(62.2 \%)$ smokers and 14 (37.8\%) non-smokers. However, in controls, smokers were less than non-smokers with 12 (32.4\%) smokers and 25 (67.6\%) non-smokers. Alcohol drinkers were less than non-drinkers both in NPC patients and controls. Alcohol drinkers in NPC patients were $4(10.8 \%)$ patients and in controls were $2(5.4 \%)$ persons while non-alcohol drinkers were $33(89.2 \%)$ in NPC patients and 35 (94.6\%) persons in controls. The frequent consumption of salted fish and preserved food was found in 28 (75.7\%) in NPC patients and $29(78.4 \%)$ in controls. There were $9(24.3 \%)$ NPC patients and $8(21.6 \%)$ persons of controls which were not frequently consuming salted fish and preserved food consumption. We found a significant association of smoking with NPC with a risk of 3.423-fold higher in smokers than non-smokers. There was no significant association of CYP2E1 polymorphism, drinking alcohol, and salted fish and preserved food consumption with NPC.

We analyzed the joint effect of CYP2E1 polymorphism with other environmental risk factors in NPC patients which are shown in Table 3. The result was there was a significant association of the joint of homozygote mutant genotype of CYP2E1 with smoking in NPC patients $(\mathrm{OR}=4.000,95 \% \mathrm{Cl}=1.205-13.283$, $p=0.007)$. It meant that in the person carrying homozygous mutant genotype of CYP2E1, the incidence of NPC differed between smokers and non-smokers with the risk in smokers was about fourfold higher than smokers. Above, the risk for NPC in smoking alone was about 3.423 and the combination of smoking and homozygote mutant genotype was higher, about four. We did not find a significant association of the joint of CYP2E1 polymorphism with drinking alcohol and the consumption of salted fish and preserved food.

Table 3: Association of CYP2E1 polymorphism with environmental factors in NPC patients

\begin{tabular}{|c|c|c|c|c|c|c|}
\hline \multirow[t]{3}{*}{ Risk factors } & \multicolumn{6}{|c|}{ Genetic variance of CYP2E1 } \\
\hline & \multicolumn{2}{|l|}{$+/+$} & \multicolumn{2}{|l|}{++-} & \multicolumn{2}{|l|}{$-1-$} \\
\hline & $\begin{array}{l}\text { Case/ } \\
\text { Control }\end{array}$ & $\begin{array}{l}\mathrm{p} \\
\text { value }\end{array}$ & $\begin{array}{l}\text { Case/ } \\
\text { Control }\end{array}$ & $\begin{array}{l}\mathrm{p} \\
\text { value }\end{array}$ & $\begin{array}{l}\text { Case/ } \\
\text { Control }\end{array}$ & $\begin{array}{l}\mathrm{p} \\
\text { value }\end{array}$ \\
\hline \multicolumn{7}{|l|}{ Smoking } \\
\hline Smokers & $13 / 10$ & $>0.05$ & $2 / 2$ & $>0.05$ & $8 / 0$ & $<0.05^{\star \star}$ \\
\hline Non-smokers & $11 / 16$ & & $1 / 3$ & & $2 / 6$ & $\begin{array}{l}\text { (OR:4.000) } \\
\text { Cl: } 1.205-13.283\end{array}$ \\
\hline \multicolumn{7}{|l|}{ Drinking alcohol } \\
\hline Drinkers & 2/1 & $>0.05$ & $1 / 1$ & $>0.05$ & $1 / 0$ & $>0.05$ \\
\hline Non-drinkers & $22 / 25$ & & $2 / 4$ & & 9/6 & \\
\hline \multicolumn{7}{|c|}{ Salted fish and preserved food consumption } \\
\hline Frequently & $18 / 21$ & $>0.05$ & $3 / 3$ & & $7 / 5$ & $>0.05$ \\
\hline Seldom & $6 / 5$ & & $0 / 2$ & $>0.05$ & $3 / 1$ & \\
\hline
\end{tabular}

\section{Discussion}

In the study, we found that most NPC patients were frequently had age in the range of 41-60 years old and then followed by the age in the range of $21-40$ years old. The result was similar to studies which had been done before. Wei et al. in their study of incidence and mortality of NPC in China found that incidence of NPC rose quickly in the age with a range of 25-29 years old with the peak age was in the range of 60-64 years old in males and 75-79 years old in females. The incidence than was decreased in the older range of age [18]. Adham et al., in Indonesia, found that the patients were diagnosed with NPC in the range of age 30-59 years old with the peak age was at 40-49 years old [8]. However, in the western area, Finland, Ruuskanen et al., found the range of age in the diagnosis of NPC was in 12-85 years old with the average age was 57 years old [19]. The incidences of NPC in the Asian as the high-risk populations rise in adolescences with the peak age at 45-55 years old and then decline. In the low risk and intermediate populations, the western area, the incidences have a bimodal pattern where the first peak at age 15-24 years old and the second peak at 65-79 years old. The bimodality pattern was thought due to the heterogeneous etiology of NPC within the same populations [20].

Male was common suffering NPC than females in this study with the ratio $2.7: 1$. Xiao et al. found $213(71.2 \%)$ males and $86(28.8 \%)$ females with NPC [21]. Xie et al. found that the overall ratio of male to female for NPC was ranged in 2.2-3.1. Male is dominant for NPC was thought related to a delayed development of cancer in females, especially before menopause. The protective effect of estrogen was thought has a role in that suggestion. Environmental factors such as smoking and salted fish and preserved food consumption are mainly found in males. It also thought of as the reason for the predominantly male in NPC [22].

In this study, non-keratinizing squamous cell carcinoma was found mostly from other histopathology types. This type is the most common in the endemic area about more than $95 \%$ cases [23], [24]. It is associated with EBV infection and more radiosensitive than other types [23], [25]. Keratinizing squamous cell carcinoma is common in the west area with low EBV, DNA is detected in patients with this histopathology type. This type is associated with smoking and has a poorer prognosis than non-keratinizing squamous cell carcinoma [26], [27]. Pan et al., in Singapore, found 103 of 111 NPC patients with non-keratinizing squamous cell carcinoma [28]. A study by Ji et al., in China, also found most histopathology type of NPC in their study was non-keratinizing squamous cell carcinoma with 932 of 1044 NPC patients [29].

Tobacco contains carcinogens, nitrosamines, and an active carcinogen metabolite that damaging DNA and induces chronic inflammation in nasopharyngeal mucosa [30]. Tobacco- specific nitrosamine is the highly carcinogenic substances in tobacco which is the product of nitrosation of nicotine that is contained in tobacco. Nitrosamine ketone (NNK) is one of the active carcinogens of tobacco-specific nitrosamine. 
It causes a mutation of oncogenes such as K-Ras and p53. Besides, NNK is also responsible for the modulation of signal-transducing networks such as the PI3K-Akt pathway. The pathway increases cell growth, proliferation, survival, migration, and metabolism [31].

In this study, the risk for NPC in smokers was 3.423 fold higher than non-smokers. A study by Ekburanawat et al. found that a significant association of smoking with NPC with the risk was 2.41-fold higher than non-smokers. The study also was similar to our findings that there was no significant association between alcohol and salted fish consumption with NPC [32]. A meta-analysis study by Xue et al. found an increased risk of NPC about 1.6-fold for smokers than non-smokers. Smokers with a cumulative exposure of $\geq 30$ pack-years had a higher risk for NPC, 2.93-fold than smokers with cumulative exposure $<30$ packyears which had the risk for NPC about 1.29-fold than non-smokers [33].

CYP2E1acts in the activation of pro-carcinogens including nitrosamines which are contained in tobacco, meat, and salted and preserved food [34], [35], [36]. This enzyme metabolizes the xenobiotic substances into toxic substances which induces carcinogens [37]. CYP2E1 also can induce ROS formation that can damaging DNA, leading to mutation and increased cell growth [38], [39]. Polymorphism of CYP2E1 had known to be associated with cancers including NPC [40], [41], [42], [43]. The polymorphism increases the transcription and activity of CYP2E1. Therefore, the activation of pro-carcinogens such as nitrosamine also increased [42], [43]. The type of CYP2E1 polymorphism which has higher enzyme activity is homozygous mutant genotype (-/-) [12]. In our study, there was no association of CYP2E1 polymorphism to NPC while the joint effect of this genetic variance with smoking was found to be significantly associated with NPC with the risk 4.0-fold higher in smokers than non-smokers. A similar result was found by Ghania et al. in their study that showed an increased risk for NPC which 3.3-fold higher in smokers than non-smokers in patients carrying homozygous mutant genotype [12].

\section{Conclusion}

We found that NPC patients were mostly male in the age group of 41-60 years old. The most common histopathology type was non-keratinizing squamous cell carcinoma. Among the risk factors, smoking was found associated with NPC while others were not related to NPC. However, the combination of the homozygous mutant genotype of CYP2E1 with smoking had a significant association with NPC that there was increased the risk for NPC in smokers which carrying homozygous mutant genotype.

\section{References}

1. Zhao $\mathrm{Y}$, Wang $\mathrm{Y}, \mathrm{Wu} \mathrm{X}$, Wang J, Zhang $\mathrm{L}$, Jia $\mathrm{Y}$, et al Quantitative assessment of the association between glutathione S-transferase M1 polymorphism and the risk of developing nasopharyngeal cancer. Oncol Lett. 2016;11(1):373-8. https:// doi.org/10.3892/ol.2015.3848

PMid:26870220

2. Li L, Gu M, You B, Shi S, Shan Y, Bao L, et al. Long non-coding RNA ROR promotes proliferation, migration, and chemoresistance of nasopharyngeal carcinoma. Cancer science. 2016;107(9):121522. https://doi.org/10.1111/cas.12989

PMid:27311700

3. Chen X, Li P, Yang Z, Mo WN. Expression of fragile histidine triad (FHIT) and WW-domain oxidoreductase gene (WWOX) in nasopharyngeal carcinoma. Asian Pac J Cancer Prevent. 2013;14(1):165-71. https://doi.org/10.7314/apjcp.2013.14.1.165 PMid:23534718

4. Qin H, Yao Y. From family study to population study: A history of genetic mapping for nasopharyngeal carcinoma (NPC). In: Applied Computational Genomics. Berlin: Springer; 2018. p. 81-106.

https://doi.org/10.1007/978-981-13-1071-3_7

5. Mahdavifar N, Towhidi F, Makhsosi BR, Pakzad R, Moini A Ahmadi A, et al. Incidence and mortality of nasopharynx cancer and its relationship with human development index in the world in 2012. World J Oncol. 2016;7(5-6):109-18. https://doi. org/10.14740/wjon980w

PMid:28983375

6. Farhat F, Daulay ER, Chrestella J, Asnir RA, Yudhistira A, Susilo RR. Correlation of P38 mitogen-activated protein kinase expression to clinical stage in nasopharyngeal carcinoma. Open Access Maced J Med Sci. 2018;6(11):1982-5. https://doi. org/10.3889/oamjms.2018.355

PMid:30559847

7. Wei KR, Zheng RS, Zhang SW, Liang ZH, Ou ZX, Chen WQ. Nasopharyngeal carcinoma incidence and mortality in China in 2010. Chinese journal of cancer. 2014;33(8):381

8. Adham M, Kurniawan AN, Muhtadi Al, Roezin A, Hermani B, Gondhowiardjo S, et al. Nasopharyngeal carcinoma in Indonesia: Epidemiology, incidence, signs, and symptoms at presentation. Chin J Cancer. 2012;31(4):185. https://doi. org/10.5732/cjc.011.10328

9. Lung ML, Cheung AKL, Ko JMY, Lung HL, Cheng Y, Dai W. The interplay of host genetic factors and Epstein-Barr virus in the development of nasopharyngeal carcinoma. Chinese journal of cancer. 2014;33(11):556. https://doi.org/10.5732/cjc.014.10170

10. Zeng MS, Zeng $Y X$. Pathogenesis and etiology of nasopharyngeal carcinoma. Nasopharyngeal Cancer: Springer; 2010. p. 9-25.

11. Dai W, Zheng H, Cheung AK, Lung ML. Genetic and epigenetic landscape of nasopharyngeal carcinoma. Chin Clin Oncol. 2016;5(2):16. PMid:27121876

12. Ghania D, Katia B, Yahia K, Monia A, Douik H, Fethi G, et al. Association between genetic polymorphisms of human cytochrome cyp2e1 and risk of nasopharyngeal carcinoma in algeria population. Int J Pharm Pharm Sci. 2018;10:76. https:// doi.org/10.22159/ijpps.2018v10i4.23389

13. Lo KW, Chung GT, To KF. Acquired genetic and epigenetic alterations in nasopharyngeal carcinoma. In: Nasopharyngeal Carcinoma. Berlin: Springer; 2013. p. 61-81.

14. Nosheen M, Ishrat M, Malik F, Baig R, Kayani M. Association of GSTM1 and GSTT1 gene deletions with risk of head and neck 
cancer in Pakistan: A case control study. Asian Pac J Cancer Prev. 2010;11(4):881-5.

PMid:21133595

15. Park JE, Seo JE, Lee JY, Kwon H. Distribution of seven N-nitrosamines in food. Toxicol Res. 2015;31(3):279-88. https:// doi.org/10.5487/tr.2015.31.3.279

PMid:26483887

16. Fukushima S, Gi M, Kakehashi A, Wanibuchi $H$. Qualitative and quantitative assessments on low-dose carcinogenicity of genotoxic hepatocarcinogens: Dose response for key events in rat hepatocarcinogenesis. In: Thresholds of Genotoxic Carcinogens. Amsterdam, Netherlands: Elsevier; 2016. p. 1-17. https://doi.org/10.1016/b978-0-12-801663-3.00001-7

17. Smith MT, Guyton KZ, Gibbons CF, Fritz JM, Portier CJ, Rusyn I, et al. Key characteristics of carcinogens as a basis for organizing data on mechanisms of carcinogenesis. Environ Health Perspect. 2015;124(6):713-21. https://doi.org/10.1289/ ehp.1509912

PMid:26600562

18. Wei KR, Zheng RS, Zhang SW, Liang ZH, Li ZM, Chen WQ. Nasopharyngeal carcinoma incidence and mortality in China, 2013. Chin J Cancer. 2017;36(1):90. https://doi.org/10.1186/ s40880-017-0257-9

PMid:25096544

19. Ruuskanen $\mathrm{M}$, Irjala $\mathrm{H}$, Minn $\mathrm{H}$, Vahlberg $\mathrm{T}$, Randen-Brady $\mathrm{R}$, Hagström J, etal. Epstein-Barr virus and human papillomaviruses as favorable prognostic factors in nasopharyngeal carcinoma: A nationwide study in Finland. Head Neck. 2019;41(2):349-57. https://doi.org/10.1002/hed.25450

PMid:30549170

20. Feng BJ. Descriptive, environmental and genetic epidemiology of nasopharyngeal carcinoma. In: Nasopharyngeal Carcinoma. Berlin: Springer; 2013. p. 23-41. https://doi. org/10.1007/978-1-4614-5947-7_3

21. Xiao G, Cao Y, Qiu X, Wang W, Wang Y. Influence of gender and age on the survival of patients with nasopharyngeal carcinoma. BMC Cancer. 2013;13(1):226. https://doi. org/10.1186/1471-2407-13-226

22. Xie SH, Yu IT, Tse LA, Mang OW, Yue L. Sex difference in the incidence of nasopharyngeal carcinoma in Hong Kong 19832008: Suggestion of a potential protective role of oestrogen. Eur J Cancer. 2013;49(1):150-5. https://doi.org/10.1016/j. ejca.2012.07.004

PMid:22892061

23. Umar B, Ahmed R. Nasopharyngeal carcinoma, an analysis of histological subtypes and their association with EBV, a study of 100 cases of Pakistani population. Asian J Med Sci. 2014;5(4):16-20. https://doi.org/10.3126/ajms.v5i4.9592

24. Chua ML, Wee JT, Hui EP, Chan AT. Nasopharyngeal carcinoma. Lancet. 2016;387(10022):1012-24. https://doi.org/10.1016/ s0140-6736(15)00055-0

PMid:26321262

25. Colaco RJ, Betts G, Donne A, Swindell R, Yap BK, Sykes AJ, et al. Nasopharyngeal carcinoma a retrospective review of demographics, treatment and patient outcome in a single centre. Clin Oncol. 2013;25(3):171-7. https://doi.org/10.1016/j. clon.2012.10.006

PMid:23337060

26. Kamran SC, Riaz N, Lee N. Nasopharyngeal carcinoma. Surg Oncol Clin. 2015;24(3):547-61. PMid:25979399

27. Tang LL, Chen WQ, Xue WQ, He YQ, Zheng RS, Zeng YX, et al. Global trends in incidence and mortality of nasopharyngeal carcinoma. Cancer Lett. 2016;374(1):22-30. https://doi. org/10.1016/j.canlet.2016.01.040

\section{PMid:26828135}

28. Pan J, Tang T, Xu L, Lu JJ, Lin S, Qiu S, et al. Prognostic significance of expression of cyclooxygenase-2, vascular endothelial growth factor, and epidermal growth factor receptor in nasopharyngeal carcinoma. Head Neck. 2013;35(9):1238-47. https://doi.org/10.1002/hed.23116

PMid:22972415

29. Ji X, Zhang W, Xie C, Wang B, Zhang G, Zhou F. Nasopharyngeal carcinoma risk by histologic type in central China: Impact of smoking, alcohol and family history. Int $\mathrm{J}$ Cancer. 2011;129(3):724-32. https://doi.org/10.1002/ijc.25696 PMid:20878958

30. Yong SK, Ha TC, Yeo MC, Gaborieau V, McKay JD, Wee J. Associations of lifestyle and diet with the risk of nasopharyngeal carcinoma in Singapore: A case-control study. Chin J Cancer. 2017;36(1):3. https://doi.org/10.1186/s40880-016-0174-3 PMid:28063457

31. Yalcin E, de la Monte S. Tobacco nitrosamines as culprits in disease: Mechanisms reviewed. J Physiol Biochem. 2016;72(1):107-20. https://doi.org/10.1007/s13105-016-0465-9 PMid:26767836

32. Ekburanawat W, Ekpanyaskul C, Brennan P, Kanka C, Tepsuwan $\mathrm{K}$, Temiyastith $\mathrm{S}$, et al. Evaluation of non-viral risk factors for nasopharyngeal carcinoma in Thailand: Results from a casecontrol study. Asian Pac J Cancer Prev. 2010;11(4):929-32. PMid:21133603

33. Xue WQ, Qin HD, Ruan HL, Shugart YY, Jia WH. Quantitative association of tobacco smoking with the risk of nasopharyngeal carcinoma: A comprehensive meta-analysis of studies conducted between 1979 and 2011. Am J Epidemiol. 2013;178(3):325-38. https://doi.org/10.1093/aje/kws479

PMid:23785114

34. Gao J, Wang GJ, Wang Z, Gao N, Li J, Zhang YF, et al. High CYP2E1 activity correlates with hepatofibrogenesis induced by nitrosamines. Oncotarget. 2017;8(68):112199-210. https://doi. org/10.18632/oncotarget.22937 PMid:29348818

35. García-Suástegui W, Ramos-Chávez L, Rubio-Osornio $M$, Calvillo-Velasco M, Atzin-Méndez J, Guevara J, et al. The Role of CYP2E1 in the Drug Metabolism or Bioactivation in the Brain. Oxid Med Cell Longev. 2017;2017:4680732. https://doi. org/10.1155/2017/4680732 PMid:28163821

36. Kao JH, Amarapurkar D, Fan JG. NAFLD in Chinese and South Asian People. United States: Non-Alcoholic Fatty Liver; 2013. p. 206. https://doi.org/10.1002/9781118556153.ch18

37. Jiménez-Garza O, Baccarelli AA, Byun HM, Márquez-Gamiño S, Barrón-Vivanco BS, Albores A. CYP2E1 epigenetic regulation in chronic, low-level toluene exposure: Relationship with oxidative stress and smoking habit. Toxicol Appl Pharmacol. 2015;286(3):207-15. https://doi.org/10.1016/j.taap.2015.04.016 PMid:25963742

38. Zanger UM, Schwab M. Cytochrome P450 enzymes in drug metabolism: Regulation of gene expression, enzyme activities, and impact of genetic variation. Pharmacol Ther. 2013;138(1):103-41. https://doi.org/10.1016/j. pharmthera.2012.12.007 PMid:23333322

39. Klaunig JE, Kamendulis LM, Hocevar BA. Oxidative stress and oxidative damage in carcinogenesis. Toxicol Pathol. 2010;38(1):96-109. https://doi.org/10.1177/0192623309356453 PMid:20019356

40. Takamori J, Santos M, Peterle G, Rossi L, Curioni O, Gazito D, et al. Alcohol metabolizing gene polymorphisms and their relationship with oral cancer risk and clinicopathological. 
Genet Mol Res 2017;16:gmr16039829. https://doi.org/10.4238/ gmr16039829

41. Karakoc MD, Kortunay S, Kara CO, Topuz B. CYP2E1 and ALDH2 gene polymorphisms in squamous cell head and neck Cancer in the Turkish population. Int $\mathrm{J}$ Hematol Oncol. 2019;29(2):61-9.

42. Jia $W H$, Pan $Q H$, Qin HD, Xu YF, Shen GP, Chen L, et al. A case control and a family-based association study revealing an association between CYP2E1 polymorphisms and nasopharyngeal carcinoma risk in Cantonese. Carcinogenesis. 2009;30(12):2031-6. https://doi.org/10.1093/carcin/bgp239 PMid: 19805575

43. Yao K, Qin H, Gong L, Zhang R, Li L. CYP2E1 polymorphisms and nasopharyngeal carcinoma risk: A meta-analysis. Eur Arch Otorhinolaryngol. 2017;274(1):253-9. https://doi.org/10.1007/ s00405-016-4236-6

PMid:27491320 